\title{
Volume estimation of existing and potential glacier lakes, Sikkim Himalaya, India
}

\author{
S. N. Remya ${ }^{1, *}$, Anil V. Kulkarni ${ }^{1}$, S. Pradeep ${ }^{1}$ and D. G. Shrestha ${ }^{2}$ \\ ${ }^{1}$ Divecha Centre for Climate Change, Indian Institute of Science, Bengaluru 560 012, India \\ ${ }^{2}$ Sikkim State Council of Science and Technology, Department of Science and Technology and Climate Change, Development Area, \\ Gangtok 737 101, India
}

\begin{abstract}
Glacial lake outburst floods (GLOFs) are a hazard commonly reported in the glaciated terrain of the $\mathrm{Hi}$ malaya. Glacier lakes can form if the glaciers retreat and the bottom topography overdeepens. We have adopted a technique to estimate the depth and volume of lakes using parameters such as glacier surface velocity, slope and laminar flow of ice. The technique has been automated using Python programming language. The method was applied in the Sikkim Himalaya to map potential lake sites and also to predict further expansion of existing glacier lakes. Studies were carried out for ten glaciers in the Tista river basin. The analysis suggests nine potential lake sites, including further expansion of four existing glacier lakes. To validate the results, the model lake boundary in 2001 was compared with the satellite-observed value of 2015 and field measurements made at the South Lhonak lake. The volume of the South Lhonak lake (in 2015) was estimated as $60 \pm 10.8$ million $\mathrm{m}^{3}$; with prolonged retreat of the glacier, the lake is likely to expand to a maximum volume of $90 \pm 16.2$ million $\mathrm{m}^{3}$. The above technique can provide new information to planners, leading to a more realistic approach in understanding the disaster potential of glacier lakes.
\end{abstract}

Keywords: Glacier lakes, depth and volume estimation, remote sensing, disaster potential, over deepening.

IN recent decades, the Himalayan glaciers are thinning and retreating due to changes in climate ${ }^{1-3}$. Depending upon geomorphological conditions, retreating glaciers can lead to the formation of moraine-dammed lakes ${ }^{4,5}$. If overdeepening is sufficiently large, it results in further expansion of the lake and this could be a potential source of flash floods. Many such flash floods have been reported in the Himalaya. One of the earliest glacial lake outburst floods (GLOFs) was reported in the Shyok glacier, Jammu and Kashmir, India in 1926, which destroyed Abudan village and the surrounding land ${ }^{6}$. Other events were reported in the Kinnaur valley, Himachal Pradesh during 1981 and 1988 (ref. 7). In addition, the flash flood in Kedarnath in 2013 with heavy rainfall in

\footnotetext{
*For correspondence. (e-mail: remyannamboodiri@gmail.com)
}

the surrounding areas was possibly due to an outburst of the Chorabari lake ${ }^{8}$. To assess future floods, estimation of potential volume of new glacier lakes and further expansion of existing lakes is needed ${ }^{9,10}$.

Remote sensing techniques have been extensively used to identify and monitor moraine-dammed lakes in the Himalaya $^{11-16}$. These studies were carried out in the Satluj, Chenab, Ganga, Tista, Chandra, Zanskar and Central Himalayan river basins, where a large number of glacier lakes were identified. Several of these lakes were reported as dangerous with the potential to cause flash floods, depending on their size and temporal behaviour $^{17,18}$. It is difficult to estimate the potential hazard from these observations due to the lack of information on depth, as remote sensing techniques cannot easily estimate depth of the lake. Therefore, approaches based on area-volume scaling were used to estimate the lake volume ${ }^{19-23}$. However, this technique showed a large variation in volume estimates, as the scaling relationship was developed using limited data. These scaling techniques are not useful to forecast future expansion and identify potential glacier lake sites. Hence a method based on velocity, slope and laminar flow equations was adopted to estimate the location and volume of potential lakes ${ }^{4,24}$. This method was standardized for Chhota Shigri glacier in the Himalaya and Glacier de Corbassière in the Swiss $\mathrm{Alps}^{4,24}$. This method has been compared with other techniques to estimate ice thickness ${ }^{25}$. In the present study, the method was applied to glaciers in the Sikkim Himalaya and lake volume was validated. This has provided important information on potential lake sites and further expansion of existing glacier lakes in the Tista river basin. The data would be valuable for modelling GLOF impacts and planning mitigation measures in Sikkim.

\section{Study area and data}

Studies were carried out in the Sikkim Himalaya. Initially, 10 glaciers covering an area of 136 sq. km were selected, wherein 4 glaciers have moraine-dammed lakes (Figure 1). Landsat ETM+ imagery of 2001/2002 and Landsat 8 (OLI/TIRS) imagery of 2015 were downloaded from the United States Geological Survey (USGS) website (https:// earthexplorer.usgs.gov/) to estimate surface velocity of the 


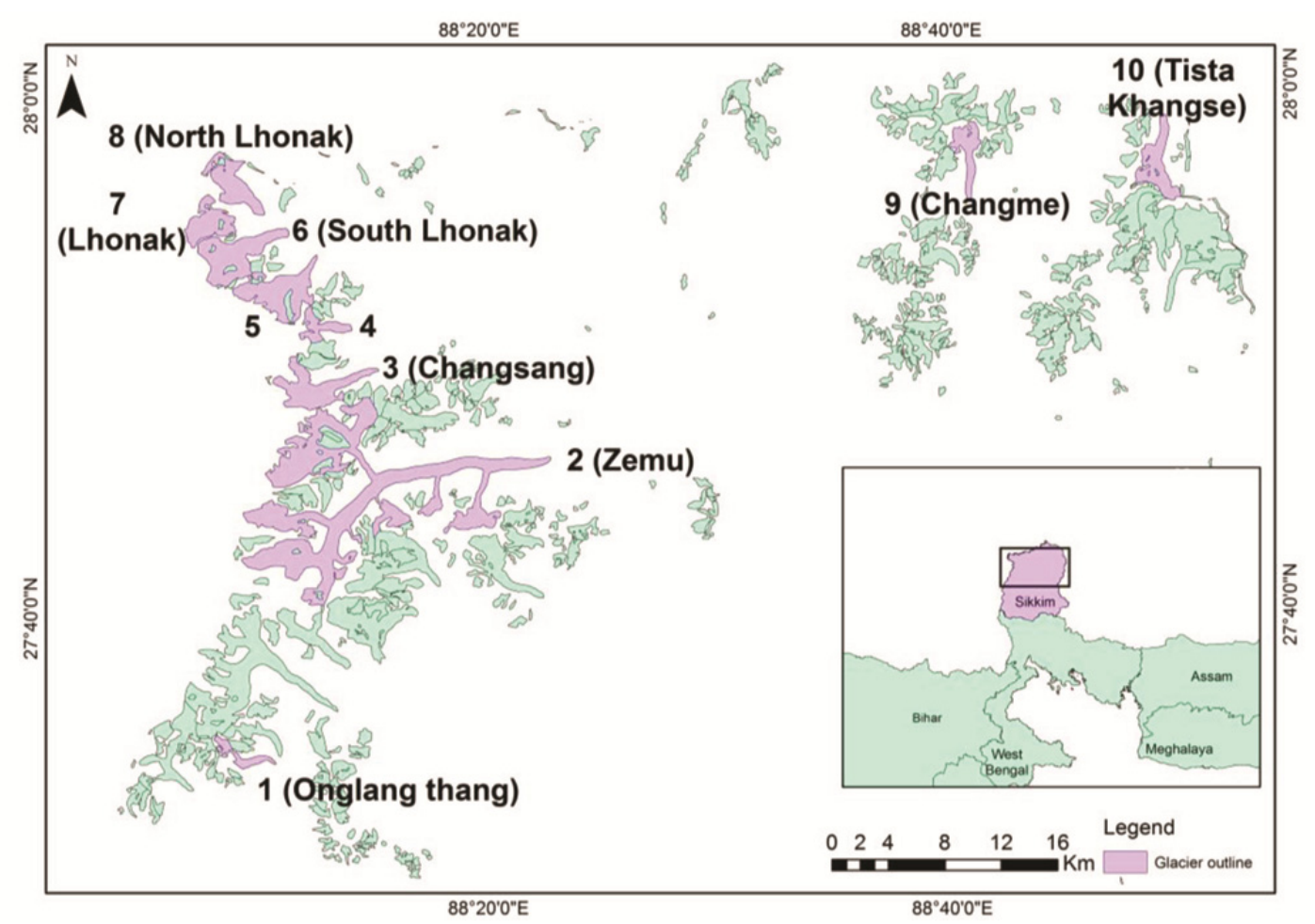

Figure 1. Location map of the glaciers in the present study.

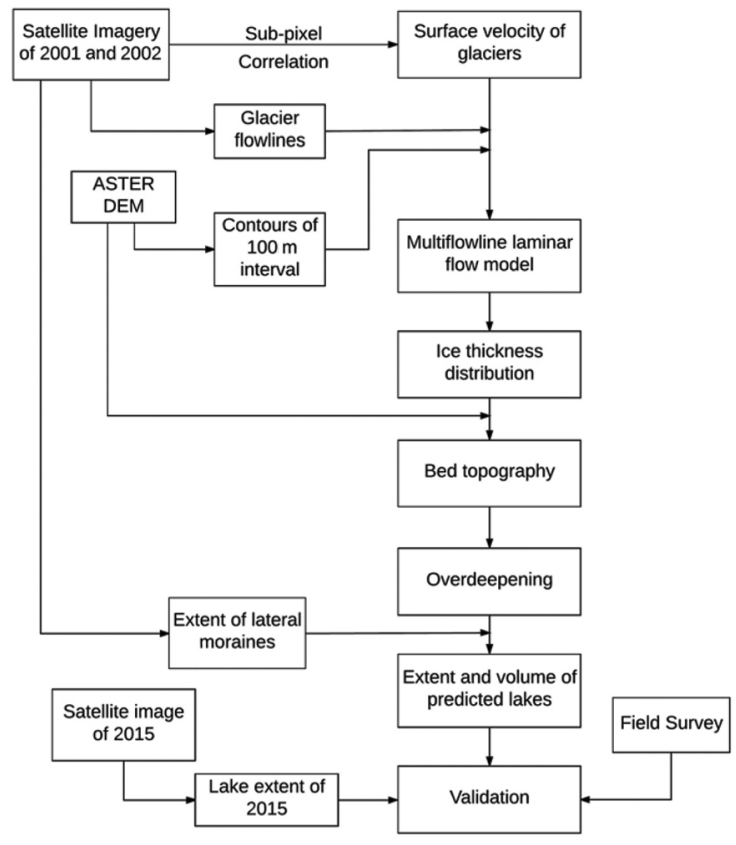

Figure 2. Flowchart showing methodology for estimation of volume of glaciers and lakes.

glaciers. The glacier boundaries were obtained from the Randolph Glacier Inventory (RGI) and Advanced Speaceborne Thermal Emission and Reflection Radiometer Digital Elevation Model (ASTER DEM) (http://reverb. echo.nasa.gov/reverb). The horizontal posting of ASTER DEM is $30 \mathrm{~m}$ and vertical posting $17 \mathrm{~m}$.

\section{In situ data}

The bathymetric data of South Lhonak lake were collected from an executive summary report 'South Lhonak glacial lake outburst flood, North Sikkim ${ }^{26}$. Field studies were carried out at the South Lhonak lake from 28 to 30 August 2014. The field survey included bathymetry survey to compute volume of water and resistivity survey to infer subsurface lithology and composition of terminal moraine. Electrical resistivity was used to estimate layered structure of sediments and distribution of ice below the moraines. Depth measurements and GPS locations were taken at approximately 200 points. The points were selected randomly and the Hondex PS-7 Depth Sounder was used for measurements. The instrument has a maximum measuring capacity of $80 \mathrm{~m}$. In addition, a follow-up survey at the South Lhonak lake was done on 28 August 2016 by Sharma et al. ${ }^{23}$ using Hondex HE-770, which can estimate depth from 3 to $500 \mathrm{~m}$. The accuracy of GPS used in the survey is $1-3 \mathrm{~m}$ and mean error for the echo sounder data is $2-3 \mathrm{~m}$.

\section{Methodology}

To estimate the potential sites and volume of glacial lakes, the following steps were used: (i) Initially, glaciers were identified from satellite imagery of 2001 and 2002. (ii) The surface velocity of the glaciers was estimated using COSI-Corr method and depth was modelled using laminar flow of ice. (iii) A DEM and depth were used to 
estimate the bottom topography and overdeepening of the bed. (iv) To validate the results, the model-predicted glacier boundary in 2001 was compared with actual expanded boundary in 2015, which was obtained from satellite data. Field campaign was carried out in 2014 to validate depth measurements. The detailed methodology (Figure 2) is as follows.

The surface velocities of all ten glaciers were estimated by sub-pixel correlation of Landsat Panchromatic band pair (15 m spatial resolution) using the Co-registration of Optically Sensed Images and Correlation (COSI-Corr) software $^{24,27}$. To perform the correlation process between two images, a moving window of $32 \times 32$ pixels and a step size of two pixels were considered. The correlated outputs are N/S displacement, E/W displacement and signal-to-noise ratio (SNR) images. All pixels having $\mathrm{SNR}<0.9$ were discarded in order to remove the erroneous pixels. A vector field was then generated from the two displacement images that represent the direction of flow. The glaciers which have proper displacement vectors were considered to determine the magnitude of the Eulerian displacement. The difference between the acquisition time of two images was calculated to estimate the velocity of the glacier. Then, multiple flowlines were delineated manually considering the medial moraines on the glacier ${ }^{28}$. The estimation of depth along the flowline was done using the laminar flow equation ${ }^{4,24,25,29}$

$$
U_{\mathrm{s}}=U_{\mathrm{b}}+\frac{2 A}{n+1} \tau_{\mathrm{b}}^{n} H
$$

where $U_{\mathrm{s}}$ and $U_{\mathrm{b}}$ are velocities at the surface and base respectively. $U_{\mathrm{b}}$ is assumed to be $25 \%$ of $U_{\mathrm{s}}$ (refs 24,30 ). $H$ is the thickness of ice $(\mathrm{m}), A$ the creep parameter (which depends on temperature, fabric, grain size and impurity content and assigned a value of $3.24 \times 10^{-24} \mathrm{~Pa}^{-3} \mathrm{~s}^{-1}$ for temperate glaciers $)^{29}$ and the Glen's flow law exponent, $n$ is assumed to be 3 . The basal stress $\left(\tau_{\mathrm{b}}\right)$ is modelled as

$$
\tau_{\mathrm{b}}=f \rho g H \sin \alpha,
$$

where $\rho$ is the ice density, assigned a constant value of $900 \mathrm{~kg} \mathrm{~m}^{-3}$ in the present study ${ }^{31} ; g$ the acceleration due to gravity $\left(=9.8 \mathrm{~ms}^{-2}\right)$ and $f$ is the shape factor (a constant value of 0.8 was used). Slope $\alpha$, was estimated from the ASTER DEM over elevation contours of $100 \mathrm{~m}$ intervals. This interval was chosen so that the surface slope is averaged over a reference distance that is about an order of magnitude larger than the local ice thickness ${ }^{24,28,29,32}$. By combining eqs (1) and (2), we derive the equation for modelled depth of ice as

$$
H=\sqrt[4]{\frac{1.5 U_{\mathrm{S}}}{A f^{3}(\rho g \sin \alpha)^{3}}}
$$

To estimate the spatial distribution of ice thickness, the 'Topo to Raster' tool in ArcGIS was used; this utilizes the discretized thin plate spline interpolation technique for interpolation ${ }^{33}$, keeping depth of the glacier along the boundary as zero. Then, the bottom topography was estimated by subtracting glacier depth from surface elevation. The troughs in the bedrock were identified using the ArcGIS hydrology fill tool ${ }^{34}$. The difference between the filled bed and unfilled bed topography provides an estimate of overdeepening below the existing glacier. However, when the actual lake is formed, it will also depend upon the surrounding topography of the glacier. Therefore, the topography up to the lateral moraines was considered and lateral moraines were delineated by visual interpretation. The depth of existing lakes was estimated using the shape and maximum depth, with the assumption that depth decreases as a function of distance up to shore$\operatorname{line}^{35}$. In case of existing lakes, the maximum bed overdeepening over the glaciated portion, as derived from the model, was extended up to the shoreline where depth was considered zero.

The uncertainties in the modelled ice thickness estimates (based on eq. (3)) are calculated using the expres$\operatorname{sion}^{4}$

$$
\frac{\mathrm{d} H}{H}=\sqrt{\left(\frac{1}{4} \frac{\mathrm{d} U_{\mathrm{s}}}{U_{\mathrm{s}}}\right)^{2}+\left(\frac{3}{4} \frac{\mathrm{d} f}{f}\right)^{2}+\left(\frac{3}{4} \frac{\mathrm{d} \rho}{\rho}\right)^{2}+\left(\frac{3}{4} \frac{\mathrm{d} \sin \alpha}{\sin \alpha}\right)^{2}}
$$

\section{Sources of uncertainty while estimating surface velocities of glaciers from satellite images}

The mean velocity on stable ground was estimated by COSI-Corr method as $3 \mathrm{~m} /$ year. This can be considered as an error since surface velocity of stable ground is expected to be zero ${ }^{36}$. Other parameters such as coregistration of Landsat ETM+ and COSI-Corr accuracy can also introduce errors in velocity; the values are $5 \mathrm{~m}$ (ref. 37) and $1.5 \mathrm{~m} \mathrm{(} \mathrm{1/20th} \mathrm{of} \mathrm{a} \mathrm{pixel)} \mathrm{respectively}{ }^{4,27}$. The combined error in velocity was estimated as $6 \mathrm{~m} /$ year.

The error in glacier areal extent was considered as 5\% in the RGI data ${ }^{38}$. The uncertainty in the shape factor value arises due to the influence of side drag along the glacier flow lines, and it varies with width of the glacier. Considering the range of values between 0.7 (ablation) and 0.9 (accumulation) ${ }^{28,39}$, the error in shape factor was considered as $\pm 12.5 \%$ in the present analysis ${ }^{4,24}$. The uncertainty in ice density $\rho$ was taken as $10 \%$ considering the typical variation in ice density from 830 to 923 $\left(\mathrm{kg} \mathrm{m}^{-3}\right)^{13}$. The uncertainty in $\sin \alpha$ arises due to vertical inaccuracies in DEM. Due to similarity in topography and lack of ground measurement data in the present study area, values from accuracy assessment over Bhutan 


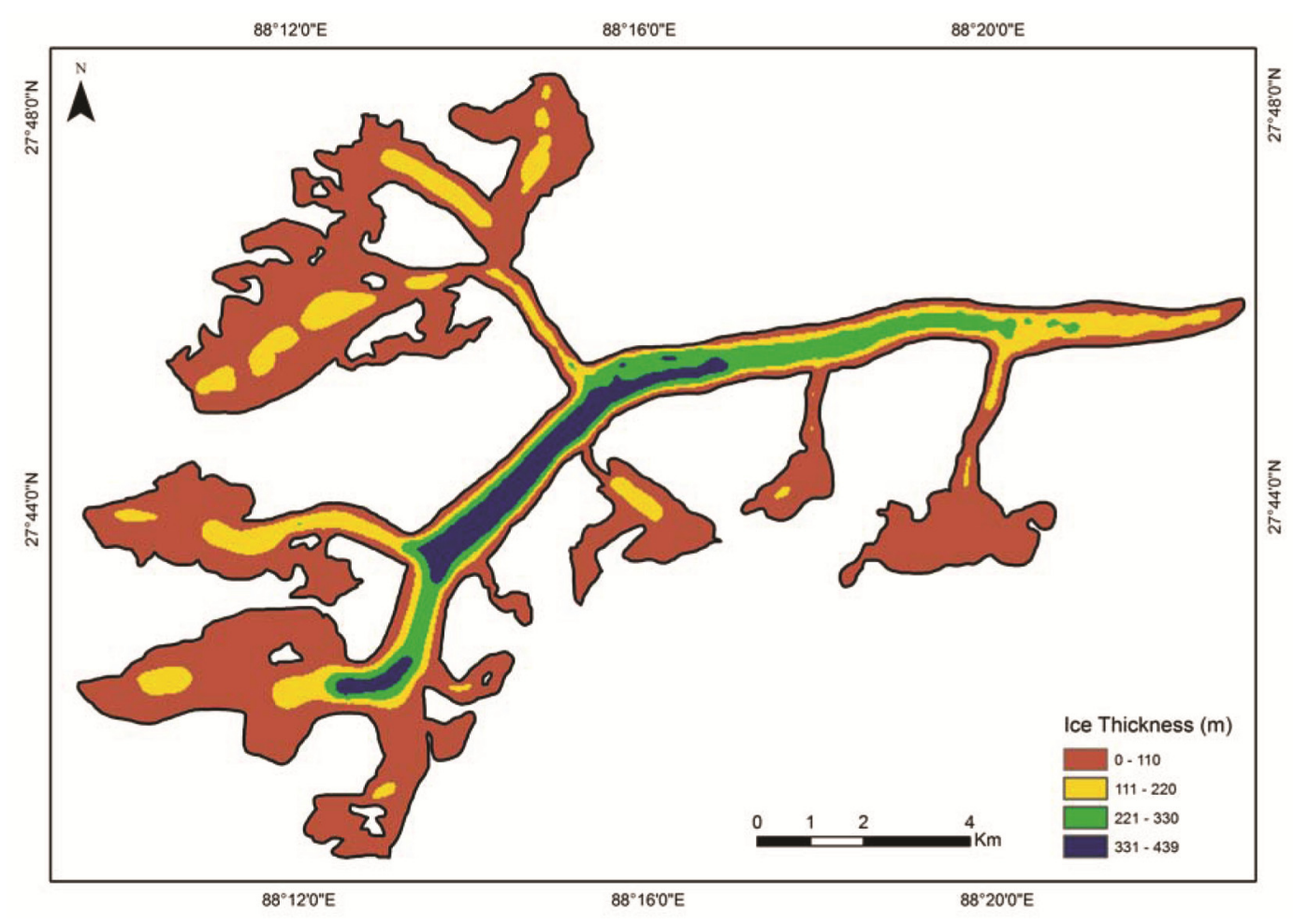

Figure 3. Thickness distribution of Zemu glacier (glacier no. 2 in Figure 1). Maximum thickness is modelled as $439 \mathrm{~m}$.

Himalaya were considered ${ }^{40}$. The value for error in $\sin \alpha$ was taken as $\pm 8.7 \%$. The total uncertainty in ice volume estimated was $18 \%$ and the same was assumed for lake volume.

\section{Development of a semi-automated tool for potential future expansion of lakes}

The method discussed here is ideal for studying a few glaciers, but can be cumbersome when applied to a larger number of glaciers. The method was partially automated using Python script, which can be used to derive information about glacier depth and lake volume. The tool uses the ArcPy module available from ArcGIS 10.1 version and is executed via a graphical user interface (GUI) built using the Tkinter module in python. This is a multipurpose tool which gives estimates of glacier thickness and potential future expansion of glacier lakes. The volume of the lake and spatial distribution of lake depth provided by the tool can be useful for hydrodynamic modelling of outburst floods and impact assessments. This tool can be applied to any glaciers for which input data are available. It requires DEM, surface velocity, glacier boundary, contour polygons and flowlines as inputs. This tool uses a velocity and slope-based model to provide the fully distributed ice thickness and future lake depth using an automated workflow. With present knowledge on glacier lakes being limited, the automated tool has the potential for use in a large number of glaciers.

\section{Results and validation}

The surface velocity of ten glaciers was estimated using COSI-Corr from the satellite images of 2001 and 2002. The velocity data suggest that the highest mean velocity is $22 \mathrm{~m} /$ year in glacier no. 6 and the lowest mean velocity is $5 \mathrm{~m} /$ year in glacier no. 8 . The mean velocity for all 10 glaciers along the flow line was estimated as $14 \mathrm{~m} /$ year. The ice thickness distribution has been estimated for the ten glaciers using laminar flow model. The maximum ice thickness was observed in Zemu glacier (glacier no. 2) as $439 \pm 57 \mathrm{~m}$ and Figure 3 shows the spatial distribution of ice thickness. The maximum ice volume of $5.7 \pm 1 \mathrm{~km}^{3}$ was estimated for the same glacier (glacier no. 2) with an area of $69 \pm 3.4 \mathrm{sq} . \mathrm{km}$ (Table 1). The total volume of the 10 glaciers in Tista Basin was estimated as $9.75 \pm$ $1.8 \mathrm{~km}^{3}$.

The bed topography of all the glaciers was estimated from the spatial distribution of glacier depth and surface topography. Subsequently, overdeepening of the lakes (in the ten glaciers) and their volumes were estimated (Figures 4 and $5 c$ ). However, no overdeepening was observed in the Zemu glacier (glacier no. 2). The total volume of the nine lakes was estimated as $149 \pm 26$ million $\mathrm{m}^{3}$ in 2001 and $246 \pm 44$ million $\mathrm{m}^{3}$ in 2015 . Therefore, increase in volume of the lakes from 2001 to 2015 was $97 \pm 17$ million $\mathrm{m}^{3}$, which included the formation of two new lakes near the terminus of glacier nos 3 and 5 (Figure 4). The lake near the terminus of Tista Khangse glacier 

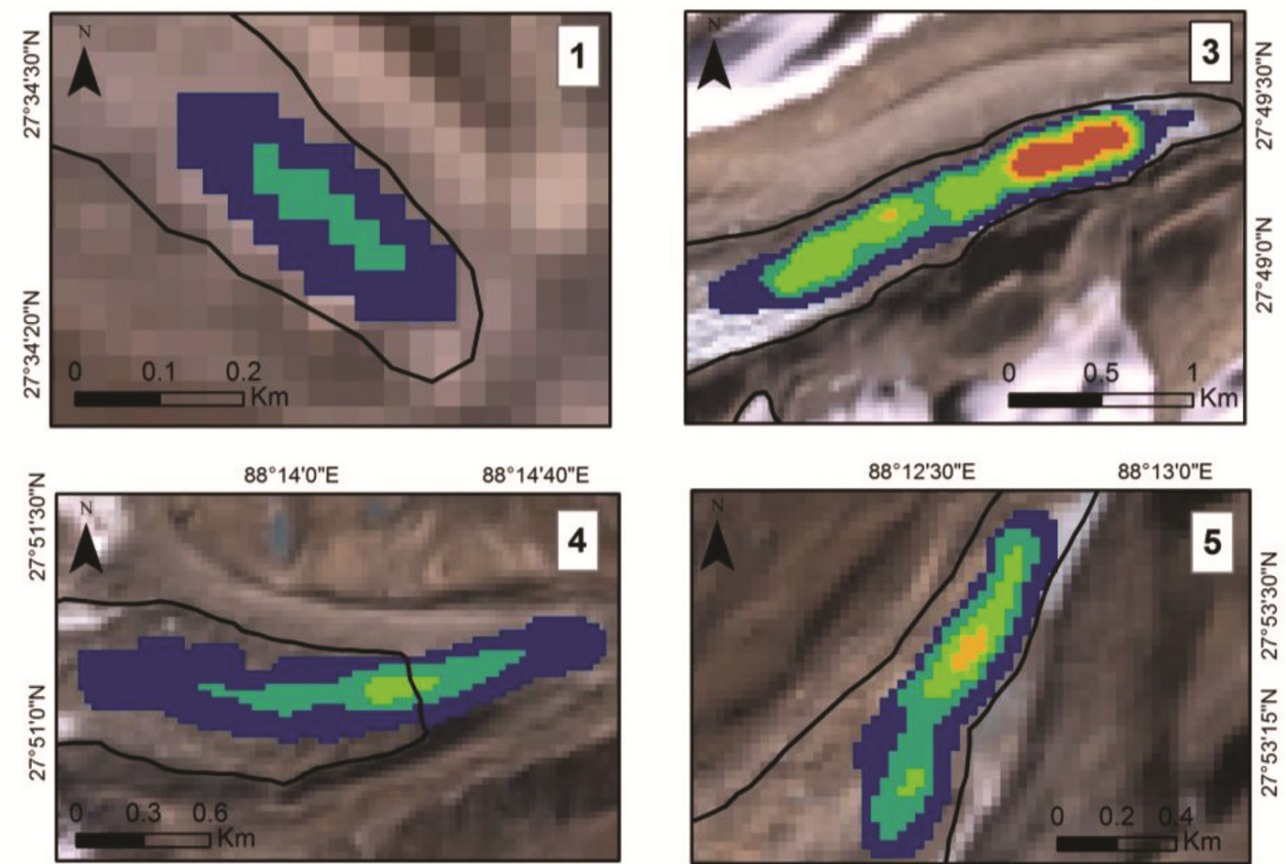

$88^{\circ} 9^{\prime} 10^{\prime \prime} \mathrm{E}$

$88^{\circ} 10^{\prime} 0 " \mathrm{E}$
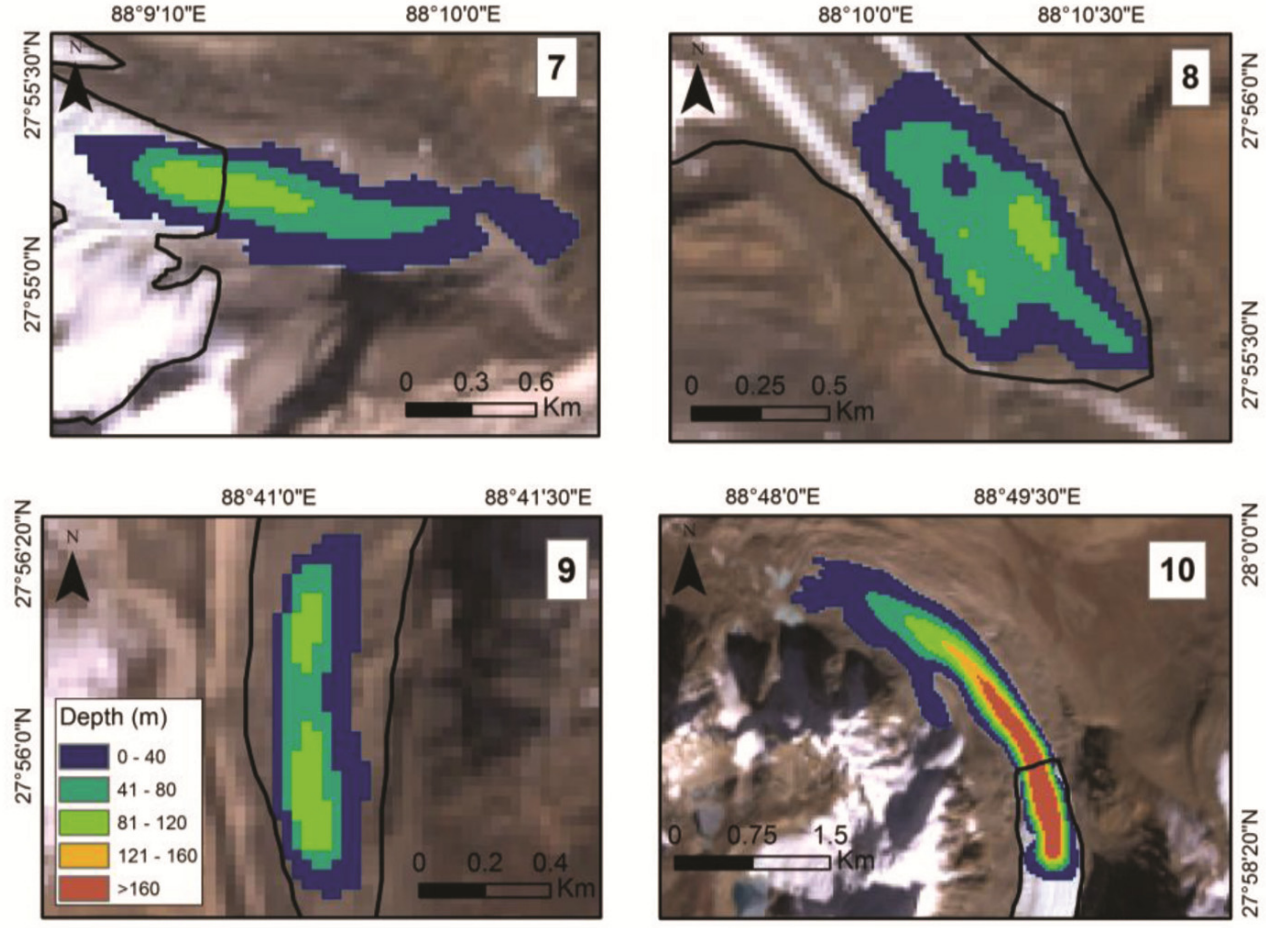

Figure 4. Overdeepening in all glaciers, excepts glacier nos 2 and 6. Further expansion of the four existing glacier lakes can be seen in glaciers nos 4, 6, 7 and 10 .

(glacier no. 10) showed maximum predicted depth of $279 \mathrm{~m}$; it also showed maximum modelled volume of 150 million $\mathrm{m}^{3}$ with an area of $2.2 \mathrm{sq} . \mathrm{km}$.

The modelled depth of ice in the South Lhonak glacier was as high as $250 \mathrm{~m}$ in the accumulation area and $60 \mathrm{~m}$ in the ablation area, and bed topography distribution of the glacier was between 5006 and $7434 \mathrm{~m}$ asl. Satellite images of 2001 and 2015 suggest an expansion of the lake from 0.80 to $1.30 \mathrm{sq}$. $\mathrm{km}$ the this time interval (Figure $5 a$ and $b$ ). In addition, the model suggests that it will further expand up to an area of $1.90 \mathrm{sq}$. $\mathrm{km}$ (Figure $5 \mathrm{c}$ ). The modelled volume of the lake during 2015 was estimated as 60 million $\mathrm{m}^{3}$. With further retreat of the glacier, the lake can grow to a maximum predicted volume of 
RESEARCH ARTICLES

\begin{tabular}{|c|c|c|c|c|c|c|c|c|}
\hline \multirow[b]{2}{*}{ Number } & \multicolumn{2}{|c|}{ Glacier } & \multicolumn{3}{|c|}{ Lake area } & \multicolumn{3}{|c|}{ Lake volume } \\
\hline & $\begin{array}{l}\text { Area } \\
\left(\mathrm{km}^{2}\right)\end{array}$ & $\begin{array}{l}\text { Volume } \\
\left(\mathrm{km}^{3}\right)\end{array}$ & $\begin{array}{c}\text { In } 2001 \\
\left(\mathrm{~km}^{2}\right)\end{array}$ & $\begin{array}{c}\text { In } 2015 \\
\left(\mathrm{~km}^{2}\right)\end{array}$ & $\begin{array}{l}\text { Maximum } \\
\text { area }\left(\mathrm{km}^{2}\right)\end{array}$ & $\begin{array}{l}\text { In } 2001 \\
\left(10^{6} \mathrm{~m}^{3}\right)\end{array}$ & $\begin{array}{l}\text { In } 2015 \\
\left(10^{6} \mathrm{~m}^{3}\right)\end{array}$ & $\begin{array}{c}\text { Maximum } \\
\text { volume }\left(10^{6} \mathrm{~m}^{3}\right)\end{array}$ \\
\hline 1 & 2.5 & 0.2 & - & - & 0.05 & - & - & 1 \\
\hline 3 & 10 & 0.9 & - & 0.5 & 0.9 & - & 40 & 60 \\
\hline 4 & 3.5 & 0.15 & 0.2 & 0.35 & 0.7 & 7 & 10 & 20 \\
\hline 5 & 11.5 & 0.6 & - & 0.07 & 0.3 & - & 3 & 15 \\
\hline 6 & 12 & 0.7 & 0.8 & 1.3 & 1.9 & 29 & 60 & 90 \\
\hline 7 & 7 & 0.3 & 0.6 & 0.8 & 0.85 & 20 & 28 & 29 \\
\hline 8 & 8 & 0.5 & - & - & 0.6 & - & - & 25 \\
\hline 9 & 5 & 0.3 & - & - & 0.3 & - & - & 10 \\
\hline 10 & 7.2 & 0.4 & 1.7 & 1.8 & 2.2 & 93 & 105 & 150 \\
\hline
\end{tabular}
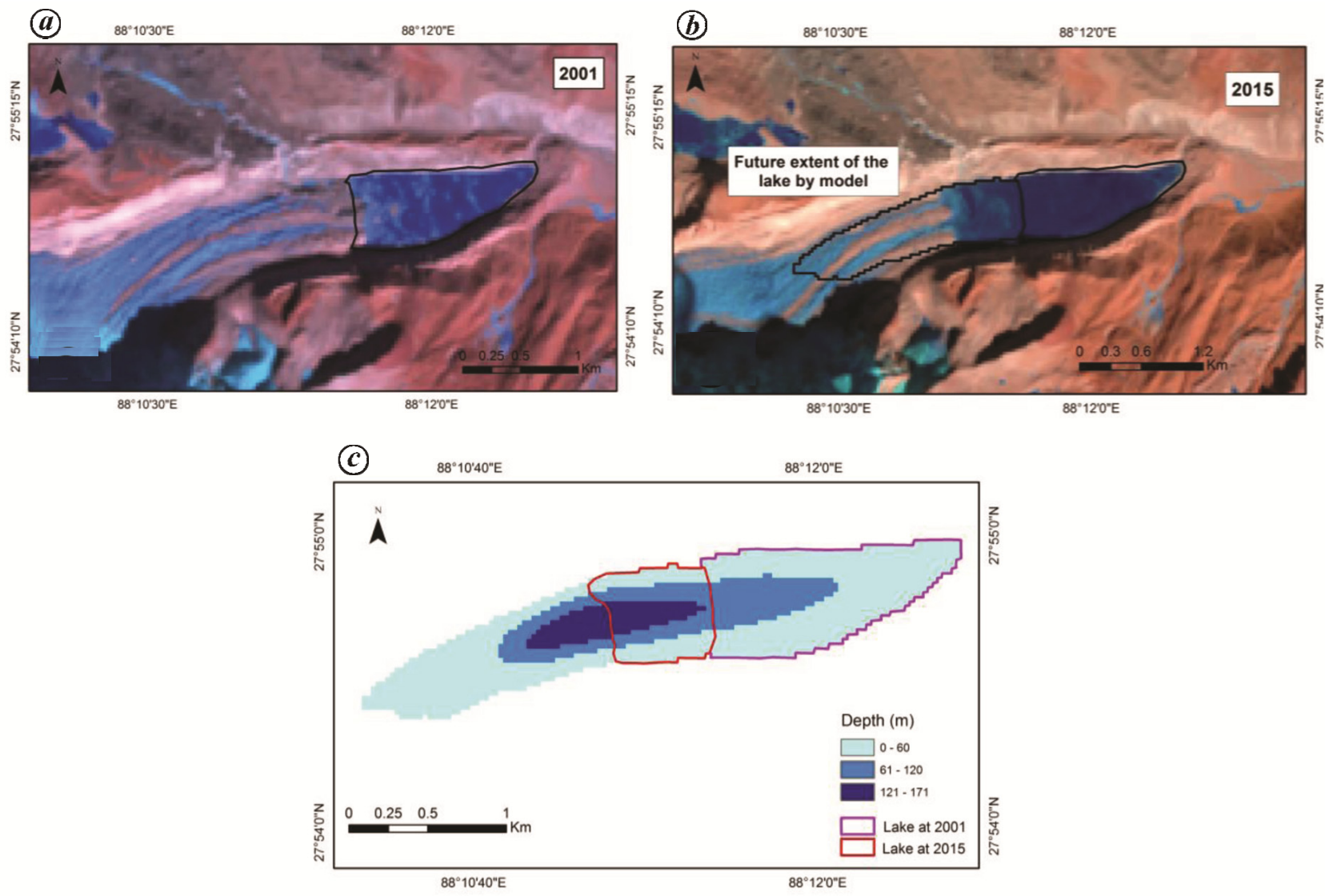

Figure 5. South Lhonak lake in (a) 2001 and (b) in 2015, including the extent of future prediction. (c) Predicted lake formation along with depth values.

90 million $\mathrm{m}^{3}$ (Table 1). The maximum and average depth of the lake when it reaches its maximum extent was estimated to be $170 \pm 30.6$ and $49 \pm 8.8 \mathrm{~m}$ respectively.

Field observations based on surveys in 2014 and 2016 suggested that volume of the lake was $65.81 \pm 3$ million $\mathrm{m}^{3}$, which is close to the model-derived value of $60 \pm$ 10.8 million $\mathrm{m}^{3}$. The difference may due to some uncertainties in the model and due to limitation of field instrument. The maximum depth of the lake from bathymetric survey was $131 \pm 2.5 \mathrm{~m}$, with an average depth of $67.05 \pm 2.5 \mathrm{~m}$ and the model estimated maximum and average depth in 2015 was $160 \pm 28.8$ and $51.4 \pm 9.3 \mathrm{~m}$ respectively. The area of the lake in 2015 was estimated as $1.3 \pm 0.09 \mathrm{sq} . \mathrm{km}$ from the present model, which matches with the areal extent derived by Sharma et al. ${ }^{23}$. To further compare the model estimate, field measurements were compared with depth measurements of the lake derived from 2014 field survey data. The Hondex 


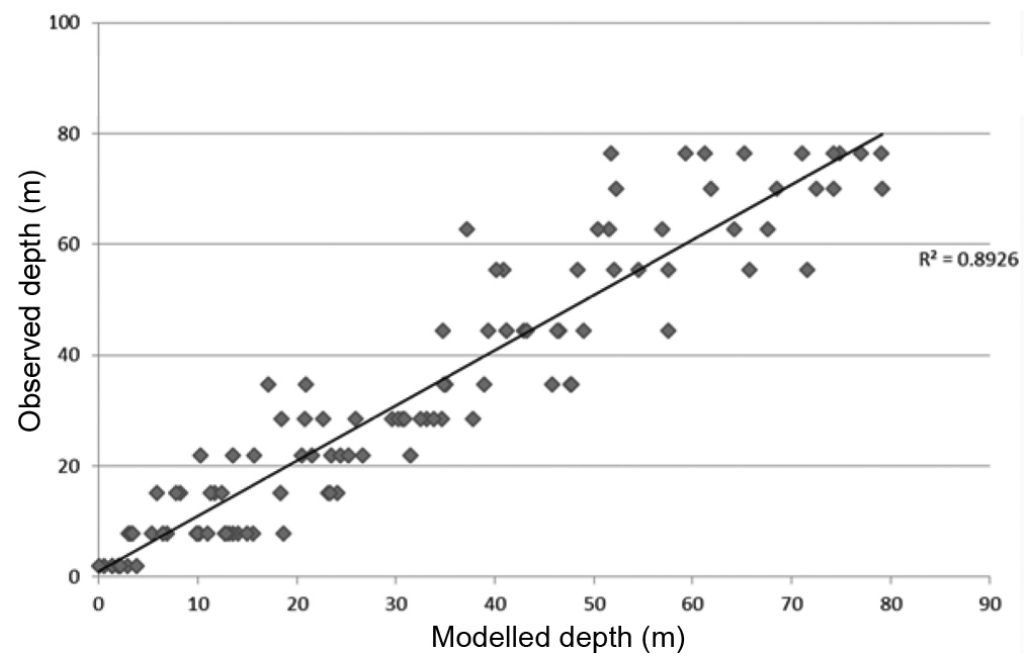

Figure 6. Scatter plot showing correlation between field-observed (2014) and model-derived depth values (RMSE $=7.88 \mathrm{~m})$.

PS-7 Depth Sounder instrument, which was used for the first survey, can measure depth up to $80 \mathrm{~m}$. Around 110 points were compared (where modelled depth of lake was less than $80 \mathrm{~m}$ ) and RMSE was estimated as $7.8 \mathrm{~m}$ (Figure 6).

\section{Discussion and conclusion}

In this study, volume of six existing glacier lakes has been calculated. This provides useful information to the scientific community, as it is difficult to obtain such data by conventional field methods due to remote location of the glacier lakes. It is an important step towards understanding the disaster potential of existing glacier lakes. Among these lakes, modelled results of the South Lhonak lake were compared with in situ observations. The modelled volume of the South Lhonak lake was validated with the echo sounder, and was observed to be within $\sim 9 \%$ uncertainty relative to the volume derived by field measurements.

This indicates the usefulness of the present method in estimating area, depth and volume of moraine dammed lakes which are attached to glacier snouts. In addition, future expansion of the lake with volume of 90 million $\mathrm{m}^{3}$ has been predicted. This large amount of water has the potential to cause disaster in downstream regions. The present study has shown large increases in water volume in the other glacier lakes also. The volume in individual glacier lakes varies from 15 to 150 million $\mathrm{m}^{3}$. Therefore, major field studies are necessary to further understand the disaster potential. This study has also identified three new sites where lakes can form in future. The volume of such lakes is also large and ranges from 1 to 25 million $\mathrm{m}^{3}$. Hence, further monitoring of these regions is necessary. The study presents an approach based on remote sensing data and models, which can provide unique information to planners so as to provide better safety to people living in the Himalaya.

1. Kulkarni, A. V. and Karyakarte, Y., Observed changes in Himalayan glaciers. Curr. Sci., 2014, 106, 237-244.

2. Kulkarni, A. V., Bahuguna, I. M., Rathore, B. P., Singh, S. K., Randhawa, S. S., Sood, R. K. and Dhar, S., Glacial retreat in Himalaya using Indian Remote Sensing satellite data. Curr. Sci., 2007, 92, 69-74.

3. Bolch, T. et al., The state and fate of Himalayan glaciers. Science, 2012, 336, 310-314.

4. Maanya, U. S., Kulkarni, A. V., Tiwari, A., Bhar, E. D. and Srinivasan, J., Identification of potential glacial lake sites and mapping maximum extent of existing glacier lakes in Drang Drung and Samudra Tapu glaciers, Indian Himalaya. Curr. Sci., 2016, 111, 553-560.

5. Yao, X., Liu, S., Sun, M., Wei, J. and Guo, W., Volume calculation and analysis of the changes in moraine-dammed lakes in the north Himalaya: a case study of Longbasaba lake. J. Glaciol., 2012, 58(210), 753-760.

6. Mason, K., Indus floods and Shyok glaciers. Himalayan J., 1929, 1, 10-29.

7. Sangewar, C. V., Srivastava, D. and Singh, R. K., Reservoir within the Shaune Garang glacier, district Kinnaur, Himachal Pradesh. In Abstract Proceedings of the Symposium on Snow, Ice and Glaciers: A Himalayan Perspective, Geological Survey of India, 2001, 39-40.

8. Dobhal, D. P., Gupta, A. K., Mehta, M. and Khandelwal, D. D., Kedarnath disaster: facts and plausible causes. Curr. Sci., 2013, 105, 171-174.

9. Richardson, S. D. and Reynolds, J. M., An overview of glacial hazards in the Himalayas. Quaternary Int., 2000, 65, 31-47.

10. Worni, R., Huggel, C. and Stoffel, M., Glacial lakes in the Indian Himalayas from an area-wide glacial lake inventory to on-site and modeling-based risk assessment of critical glacial lakes. Sci. Total Environ., 2013, 468, S71-S84.

11. Kulkarni, A. V., Philip, G., Thakur, V. C., Sood, R. K., Randhawa, S. S. and Chandra, R., Glacier inventory of the Satluj Basin using remote sensing technique. Himalayan Geol., 1999, 20, 45-52.

12. Randhawa, S. S., Sood, R. K., Rathore, B. P. and Kulkarni, A. V., Moraine-dammed lakes study in the Chenab and the Satluj river basins using IRS data. J. Indian Soc. Remote Sensing, 2005, 33, 285-290. 
13. Bhambri, R., Mehta, M., Dobhal, D. P. and Gupta, A. K., Glacier Lake Inventory of Uttarakhand, Wadia Institute of Himalayan Geology, Dehradun, 2015, 1st edn.

14. Raj, K. B. G., Remya, S. N. and Kumar, K. V., Remote sensingbased hazard assessment of glacial lakes in Sikkim Himalaya. Curr. Sci., 2013, 104(3), 359-364.

15. Raj, K. B. G. and Kumar, K. V., Inventory of glacial lakes and its evolution in Uttarakhand Himalaya using time series satellite data. J. Indian Soc. Remote Sensing, 2016, 44, 959-976.

16. Nie, Y., Liu, Q. and Liu, S., Glacial lake expansion in the Central Himalayas by Landsat images, 1990-2010. PLoS ONE, 2013, 8, p.e 83973 .

17. Bolch, T., Peters, J., Yegorov, A., Pradhan, B., Buchroithner, M. and Blagoveshchensky, V., Identification of potentially dangerous glacial lakes in the northern Tien Shan. Nat. Hazards, 2011, 59, $1691-1714$

18. Liu, J. J., Tang, C. and Cheng, Z. L., The two main mechanisms of glacier lake outburst flood in Tibet, China. J. Mt. Sci., 2013, 10, 239-248.

19. O’Connor, J. E., Hardison, J. H. and Costa, J. E., Debris flows from failures of neoglacial-age moraine dams in the Three Sisters and Mount Jefferson Wilderness Areas, Oregon. US Geol. Surv. Prof. Pap., 2001, 1606, 1-93.

20. Huggel, C., Kääb, A., Haeberli, W., Teysseire, P. and Paul, F., Remote sensing-based assessment of hazards from glacier lake outbursts: a case study in the Swiss Alps. Can. Geotech. J., 2002, 39, 316-330.

21. Sakai, A., Glacial lakes in the Himalayas: a review on formation and expansion processes. Global Environ. Res., 2012, 16, 23-30.

22. Patel, L. K., Sharma, P., Laluraj, C. M., Thamban, M., Singh, A. and Ravindra, R., A geospatial analysis of Samudra Tapu and Gepang Gath glacial lakes in the Chandra Basin, Western Himalaya. Nat. Hazards, 2017, 86, 1275-1290.

23. Sharma, R. K., Pradhan, P., Sharma, N. P. and Shrestha, D. G. Remote sensing and in situ-based assessment of rapidly growing South Lhonak glacial lake in eastern Himalaya, India. Nat. Hazards, 2018, 93(1), 1-17.

24. Gantayat, P., Kulkarni, A. V. and Srinivasan, J., Estimation of ice thickness using surface velocities and slope: case study at Gangotri Glacier, India. J. Glaciol., 2014, 60, 277-282.

25. Farinotti, D. et al., How accurate are estimates of glacier ice thickness? Results from ITMIX, the Ice Thickness Models Intercomparison eXperiment. Cryosphere, 2017, 11, 949-970.

26. Ganju, A., Kulkarni, A. V., Dhobhal, D. P., Kumar, B., Shukla, S. P. and Shrestha, D. G., South Lhonak glacial lake outburst flood, North Sikkim, 2015 (pers. commun.).

27. Leprince, S., Barbot, S., Ayoub, F. and Avouac, J. P., Automatic and precise orthorectification, coregistration, and subpixel correlation of satellite images, application to ground deformation measurements. IEEE Trans. Geosci. Remote Sensing, 2007, 45, 1529-1558.

28. Linsbauer, A., Paul, F. and Haeberli, W., Modeling glacier thickness distribution and bed topography over entire mountain ranges with GlabTop: application of a fast and robust approach. J. Geophys. Res. Earth Surf., 2012, 117, F03007.

29. Cuffey, K. M. and Paterson, W. S. B., The Physics of Glaciers, Butterworth-Heinemann, Oxford, UK, 2010, 4th edn.

30. Swaroop, S., Raina, V. K. and Sangeswar, C. V., Ice flow of Gangotri glacier. In Proceedings of the Workshop on Gangotri Glacier (eds Srivastava, D., Gupta, K. R. and Mukerji, S.), Geological Survey of India (Spec. Publ. 80), 26-28 March 2003.

31. Farinotti, D., Huss, M., Bauder, A., Funk, M. and Truffer, M., A method to estimate the ice volume and ice-thickness distribution of alpine glaciers. J. Glaciol., 2009, 55, 422-430.

32. Kamb, B. and Echelmeyer, K. A., Stress-gradient coupling in glacier flow: I. Longitudinal averaging of the influence of ice thickness and surface slope. J. Glaciol., 1986, 32, 267-284.

33. Hutchinson, M. F., ANUDEM Version 5.3, Fenner School of Environment and Society, Australian National University, Canberra, 2011.

34. ESRI, A., ArcGIS 10.1. Environmental Systems Research Institute, Redlands, CA, USA, 2012.

35. Hollister, J. and Milstead, W. B., Using GIS to estimate lake volume from limited data. Lake Reservoir. Manage., 2010, 26, 194-199.

36. Saraswat, P., Syed, T. H., Famiglietti, J. S., Fielding, E. J., Crippen, R. and Gupta, N., Recent changes in the snout position and surface velocity of Gangotri glacier observed from space. Int. J. Remote Sensing, 2013, 34, 8653-8668.

37. Lee, D. S., Storey, J. C., Choate, M. J. and Hayes, R. W., Four years of Landsat-7 on-orbit geometric calibration and performance. IEEE Trans. Geosci. Remote Sensing, 2004, 42, 27862795.

38. Pfeffer, W. T. et al., The Randolph glacier inventory: a globally complete inventory of glaciers. J. Glaciol., 2014, 60, 537-552.

39. Haeberli, W. and Hölzle, M., Application of inventory data for estimating characteristics of and regional climate-change effects on mountain glaciers: a pilot study with the European Alps. Ann. Glaciol., 1995, 21, 206-212.

40. Fujita, K., Suzuki, R., Nuimura, T. and Sakai, A., Performance of ASTER and SRTM DEMs, and their potential for assessing glacial lakes in the Lunana region, Bhutan Himalaya. J. Glaciol., 2008, 54, 220-228.

ACKNOWLEDGEMENTS. This study was conducted in the Divecha Centre for Climate Change (DCCC), Indian Institute of Science, Bengaluru. We thank DCCC and the IMPRINT programme, Government of India for financial support. We also thank the Government of Sikkim for providing bathymetric data and the United States Geological Survey for its free data policy, which allowed us to use the LANDSAT imagery and ASTER dataset.

Received 1 September 2018; revised accepted 30 October 2018

doi: $10.18520 / \mathrm{cs} / \mathrm{v} 116 / \mathrm{i} 4 / 620-627$ 